\title{
A Language for Asia? Transnational Encounters in the Japanese Esperanto Movement, 1906-1928 ${ }^{1}$
}

In the summer of 1887, Ludovic Zamenhof, a Jewish ophthalmologist writing under the pseudonym 'Dr Esperanto', published a pamphlet in Warsaw, detailing 'Lingvo Internacia', a proposed language for international communication. This language came to be known by the name under which he wrote, growing as a movement and community that peaked in the interwar years, and continues today. Forty years after its original description, Akita Ujaku, a Japanese playwright visiting Moscow to attend the tenth anniversary of the October Revolution, found Esperanto to be the solution to a set of problems he was having, promoting its use in official meetings as well as using it for more personal encounters in Moscow and beyond.

It is perhaps surprising that this language, of European intellectual and cultural origin, drawing from European languages for much of its semantic and structural content, should gain an enthusiastic following in the Japanese twentieth century. However, Akita Ujaku's was only one example of a number of Japanese international encounters which Esperanto enabled and facilitated, and these encounters were only one aspect of a broad intellectual and social movement. In the 1920 s and into the early 1930 s in particular, Japan became home to the largest Esperanto community outside of (and larger than all but the very largest within) Europe. $^{2}$ By considering the experiences and transnational encounters of a selection of

1 Ian Rapley, University of Oxford and Cardiff University. This essay is the result of the author's doctoral research, supported by a UK Arts \& Humanities Research Council doctoral grant and draws upon material first presented at the $4^{\text {th }}$ Conference On Inter-Asian Networks (Istanbul, 2013), supported by the Social Science Research Council, New York.

2 Accurately estimating numbers of Esperantists is difficult and involves issues of definition, but see Peter G Forster, The Esperanto Movement (The Hague, Moulton) pp.20-25, for a discussion of attempts during the 1920s. Membership of the central Japanese Esperanto association, the Japana Esperanto-Instituto (the JEI), peaked in the mid 1920s at around three thousand, but there was also a wider population of learners and speakers who were not members - the distribution of texts supporting various radio courses, for example, was reported as high as 15,000 copies (Hatsushiba Takemi, Nihon Esuperanto undō-shi, (Tokyo, JEI) p.77). 
individuals who were connected with the Japanese Esperanto movement, this essay places language at the heart of transnational engagement, arguing that cross-cultural communication is only possible through some shared medium, and that the choice and nature of that medium reveals something of the underlying assumptions and form of the contact itself.

Esperanto is the most widespread example of what are known as planned, or artificial languages: languages which have been created through the deliberate work of one or more individuals, rather than those 'natural' languages which have emerged over time within a native speaking population. The nineteenth century saw a number of proposed international languages - planned languages designed with the goal of promoting greater ease of international communication. In Esperanto's case, Zamenhof hoped that greater intercourse between nations would lead to mutual affinity and thus world peace.

Although groups grew throughout the late nineteenth century, Esperanto's major breakthrough came at the turn of the century - a first international congress was held in 1906, in France, and from there they were organised regularly, supported by a growing speaking population and increasing organisation. After a setback during the First World War, the 1920s saw Esperanto growing again, reaching the highpoint of its international profile. Japanese support followed a similar pattern: the community was born around the time of the first convention in Europe, that first wave was followed by a lull in early Taishō era, and then there was a greater, more sustained wave in the wake of the peace of 1918 . Throughout the period to 1928 , the Japanese Esperanto movement was characterised by a well-integrated network, bringing a diverse set of ideological motivations together (largely amicably); it was spread across the Japanese mainland and also reached overseas colonies and settlements; and 
it featured both internal debate and theorising as well as a range of different practices and uses.

Recently there has been increasing academic recognition of the interest of Esperanto as a phenomenon in Asia. Scholars such as Ulrich Lins, Gregor Benton, Gotelind MüllerSaini, Usui Hiroyuki, and Sho Konishi have begun to explore various aspects of the history of the language in Asia, predominantly in China and Japan. ${ }^{3}$ Likewise, the Japanese Esperanto movement itself has engaged in historical work, often focusing upon patterns of resistance to the Japanese establishment during the interwar and wartime periods. ${ }^{4}$

Esperanto has a social and intellectual history in Japan beyond its presence in mediating and facilitating face-to-face transnational encounters. Not all who studied, supported or used the language engaged in physical movement across borders - for many farmers, workers, schoolchildren and others, overseas travel was impossible, but nevertheless they still felt the pull of the transnational imagination and participated in what has been described by Pheng Cheah and Bruce Robbins as 'thinking and feeling beyond the nation'. ${ }^{5}$ Whilst they studied the language, debated it, and advocated its wider use, their opportunity for practical application, and indeed transnational engagement, was limited to writing letters: many in Japan participated in what seem to have been vast networks of Esperanto correspondence - ideas and words flowing at a time when most people could not. ${ }^{6}$

3 Ulrich Lins, 'Esperanto as Language and Idea in China and Japan', Language Problems \& Language Planning, 32, no. 1 (2008); Gotelind Müller-Saini and Gregor Benton, 'Esperanto and Chinese Anarchism in the 1920s and 1930s', Language Problems \& Language Planning, 30, no.2 (2006); Hiroyuki Usui, 'Kokusaiha Kara Okkuruto Nashonarisuto He', Japana Esperantologio 4 (2010); Sho Konishi, 'Translingual World Order: Language without Culture in Post-Russo-Japanese War Japan', The Journal of Asian Studies, 72, no. 01 (2013).

4 Perhaps the most notable example is Miyamoto Masao and Oshima Yoshio, Hantaisei Esuperanto Undo-Shi (Tokyo, Sanshodo).

5 Pheng Cheah and Bruce Robbins, Cosmopolitics: Thinking and Feeling Beyond the Nation (Minnesota, University of Minnesota Press).

6 Advertisements for correspondence partners could draw thousands of replies from across the globe, and some individual relationships lasted decades, surviving wartime interruptions; see S Yoshikawa, Naka San'nin Okareta Hito (Osaka, Riveroij Sosho), and JEI, Wakayama to Esuperanto (Tokyo, Japana Esperanto- 
Whilst these are interesting topics in their own right, an examination of the face-toface transnational encounters which Esperanto inspired is also revealing. From elite students abroad and western educators in Japan during the late Meiji era, to a growth during the interwar period of a wider range of ex-patriot residents in Japan and increasingly diverse encounters abroad, a number of both Japanese and foreigners were drawn to Esperanto in the course of their travels and border crossings.

The traces which remain of this history can be hard to follow - collections of letters in private hands, fleeting encounters that were often born more from personal initiative and interest than professional vocation, bottom-up groups that received little or no official support or recognition (other than police surveillance) and magazines that were often hand-printed and short-lived. However, weaving these sometimes ephemeral threads together reveals a wide and lasting network of actors, both those seen as of ongoing historical significance and others whose names are largely forgotten; together they articulated a range of motivations for Esperanto that was unified by a common interest in looking out beyond Japan's borders to the wider world.

Significantly, this network of ideas and actions highlights the key role of language, or languages, as a fundamental element of transnational activity. If modern historians recognise language as more complex than a simple, transparent and unbiased medium through which exchange and communication takes place, the role of language in inter-cultural and interlinguistic encounters is doubly complex. Research such Douglas Howland's on the translation of political and philosophical concepts during the early Meiji period brings issues of language in cross-border flows of knowledge to the fore, but it is arguable that we still too readily

Instituto) p.19. These networks of letter writing represent a form of transnational engagement that was seemingly on a huge scale and perhaps unexpected but, lying beyond conventional archives, they are largely forgotten to historians. 
forget the difficulties involved in transnational communication, the frictions of language, in our desire to trace the higher level meanings which these encounters sought to express. ${ }^{7}$

Japanese travellers and others came to Esperanto for a range of reasons - blends of pragmatism and idealism. From a practical perspective, faced with the need to master European languages as access routes to knowledge in a wide array of disciplines, many Japanese were inspired by the idea of a language which would be easy (or at least, easier) to learn. Idealistic motivations covered a broader spectrum - religious and political views (of both left and right) motivated many, alongside more abstract notions of equality and fairness within an international setting. One place in which these issues came together and in which the questions of language underlying all transnational encounters were most visibly exposed was in a number of 'language problems' - breakdowns of communication where the overlap in linguistic abilities fell short of the demands put upon it. In these situations, which occurred in both official and unofficial settings, Esperanto was proposed as the simultaneous answer to broad, long term issues and as a practical solution to immediate barriers. There, and elsewhere, Esperanto was revealed as both an idea itself - a vision of a world unified through language - and a medium which enabled the spread of other ideas.

\section{Movement of Language: the Origins of Japanese Esperanto}

The first mentions of Esperanto in Japan came as early as 1888, in relation to another, now largely forgotten, international language project, Volapük. ${ }^{8}$ However the establishment of a working community of learners and speakers, forming a recognisable movement, did not take place until the turn of the century. Then, Esperanto reached Japan and gained a critical

7 Douglas Howland, Translating the West: Language and Political Reason in Nineteenth-Century Japan, (Hawaii, University of Hawaii Press).

8 'Kokusaigo', Yomiuri Shinbun, 19 February 1888, p.3. 
mass of advocates and users in the wake of the Russo-Japanese war. Japan's victory over Russia was one key event in the transformation of Japan's relations to the wider world, a period which saw the redefining its international status to one more close to equality with the Western powers, achieved and symbolised by military victory, the revision of the unequal treaties and the Anglo-Japanese Alliance. The Esperanto boom of 1906 represented a perhaps unlikely cultural manifestation of this changing nature in Japan's international position.

Esperanto reached Japan by a variety of routes in the years either side of the RussoJapanese war. These different routes map out a broad characterisation of late Meiji era transnationalism - elite students studying overseas, Western educators teaching in Japan, the Western language press, and Chinese students in Tokyo. ${ }^{9}$ The paths, and the range of individuals involved, can be illustrated by consideration of four of the key figures in the early years of Japanese Esperanto: Kuroita Katsumi, a conservative academic; George Edward Gauntlett, a Welsh missionary and teacher; the novelist Futabatei Shimei; and the anarchist Ōsugi Sakae. They represent not only a range of different professions and opinions, but each played a different role in establishing Esperanto in Japan as a self-supporting, grass roots movement.

Kuroita Katsumi, a lecturer in the Japanese classics at the Tokyo Imperial University, was the organiser of the first major Japanese Esperanto association, the Japana Esperantista Asocio, the JEA. He and others, including the famous Taishō era liberal, Yoshino Sakuzō, encountered Esperanto first through the western language press, printed in Japan and/or imported from abroad. In 1906, after studying for a few years, Kuroita began to promote

9 In June 1936, the major Japanese Esperanto commemorated the $30^{\text {th }}$ anniversary of organised Esperanto in Japan with a series of accounts by a variety of Japanese Esperantists describing their path to the language, in various places including Japan, continental Asia, Europe and America (La Revuo Orienta, June 1936). 
Esperanto himself, initially through an interview/article in Chokugen, the successor to the early socialist newspaper, the Heimin Shinbun, before founding the JEA on the $12^{\text {th }}$ June.

There were only ten members at the first JEA meeting, but it began to grow through exposure in the likes of the Yomiuri Shinbun and the Asahi Shinbun. Another source of new members came through the work of the second major figure in the foundation of Japanese Esperanto, George Edward Gauntlett. Gauntlett, a music teacher based in Okayama, was introduced to Esperanto by a fellow missionary/teacher; after experimenting with it for a while he began a study group in Okayama, and then a correspondence course for others further afield. Through this course, over 600 students learned Esperanto in 1905 and 1906, and they naturally fed into the JEA membership. ${ }^{10}$

From there, Esperanto grew rapidly throughout 1906, supported by the publication of a number of Japanese language texts designed for Japanese learners, rather than the European texts that they had previously had to rely upon. Whilst many of these were a response to the boom, the most successful was a book, Sekaigo Esuperanto, with a much longer gestation. ${ }^{11}$

In 1902, Futabatei Shimei, the novelist and Russian scholar, quit his post at the Tokyo School of Foreign Languages in order to visit Vladivostok and Harbin. In Vladivostok he became friends with Fjodor Postnikov, a leading Russian Esperantist who taught him the basics. In return, Futbatei promised to work on a textbook to introduce the language to Japan. ${ }^{12}$ The following year Postnikov visited Futabatei in Tokyo, where the two worked

10 Figures given for the number of students range between 677 (e.g. Hatsushiba, Nihon Esuperanto undō-shi, p.16), and 823 (La Japana Esperantisto, September 1906, p.1, reprinted by the Okayama Esperanto-Societo, 2011). A member of Gauntlett's first study group, Muramoto Tatsuzō, went on to work closely with the new JEA, providing the key link between the two (Oka Kazuta, Okayama no Esuperanto, Okayama Bunko \#108, pp.18-22).

11 There were at least 9 textbooks and dictionaries published in 1906-1907 (Nihon-Esuperanto-Gakkai, Nihon Esuperanto Undō-Shiryō: Vol 1 1906-1929 (Tokyo, JEI) p.14).

12 Postnikov had long been keen to introduce Esperanto to Asia (and Japan in particular), even going so far as to visit Nagasaki in 1894, where he left some European language pamphlets with local residents (apparently 
together on translating an existing Russian textbook into Japanese. ${ }^{13}$ It was this that was to become Sekaigo Esuperanto. However, the Russo-Japanese war intervened, delaying Futabatei's work further, such that the first volume was finally published only in 1906, coinciding with the rapid growth of the JEA. ${ }^{14}$

These then were the key foundations of the Japanese Esperanto movement: a central organisation, a critical mass of students and speakers, and a set of texts to support them. Ôsugi Sakae, the final of the four figures considered here, played a different role, helping to deepen the network of transnational links through Esperanto. Ösugi was involved with the JEA almost from its outset, writing one of, if not the, first Japanese to Esperanto translations. ${ }^{15}$ In the years following the creation of the JEA, he set up a night school in Esperanto, in particular teaching a group of Chinese students. This group, based around Liu Shipei, his wife He Zhen and others, went on to be one of the starting points of Esperanto and anarchism in China. ${ }^{16}$

Although Futabatei moved away from Esperanto, Kutoita, Gauntlett, and Ōsugi continued to participate in the movement in the years following 1907. Whilst their perspectives and motivations were different, they formed a part of what was for the most part

with no lasting impact) ('Futabatei to Esuperanto', Itō Saburo, in Takaku Takaku, Tōku No Hō E (Tokyo, Tettō Shoin) p.251).

13 Tsunetarō Fujima, Kindai Nihon Ni Okeru Kokusaigo Shisō No Tenkai (Osaka, Japana Esperanto Librokooperativo) p.45.

14 Futabatei's own relationship with Esperanto is somewhat ambiguous. Whilst he described himself as a member of the Vladivostok Esperanto Association in the introduction to Sekaigo-Esuperanto, and wrote a series of magazine articles on the language, he later cut any ties with the new movement, seeking to avoid meeting with other Esperantists (Fujima, Kokusaigo Shiso no Tenkai, p.50).

15 Although Ōsugi is sometimes referred to as a founder of the Japanese Esperanto Association, this is not strictly true, since he was in prison at the time of the first meeting (albeit studying Esperanto whilst incarcerated). His translation, an Esperanto version of the Japanese Momotarō folk tale, was written for the first JEA congress, held in late 1906 (Hatsushiba, Nihon Esuperanto Undō-Shi. p.21).

16 Gotelind Müller-Saini \& Gregor Benton, 'Esperanto and Chinese Anarchism 1907-1920: The Translation from Diaspora to Homeland', Language Problems \& Language Planning, 30, no. 1 (2006) pp.11-12. A parallel group, active in Paris around the same time, was the other key means by which anarchism and Esperanto were introduced to China. 
a well-integrated network of advocates and users, connecting various different sub-groups and outlooks within an interlinked community. Whilst they often disagreed over matters of philosophy and practice, for the first twenty five years of its existence, the Japanese Esperanto movement remained the single home to the vast majority of Japanese Esperantists, bringing together a range of different opinions, left and right, radical and conventional. In comparison to later years, the pioneers of 1906 perhaps articulated a more practical vision of their language than would become more common in later years, focusing more on questions of ease of study and communication than of equality, fairness and universal brotherhood. Nevertheless, in building the first institutions, they were responsible for the creation of a movement which, with the sole exception of a brief moment at the end of the Second World War, traces a continuous history of practice up to the present day.

\section{Encounters Through Esperanto: Japan as a Transnational Hub}

The outbreak of war in Europe in 1914 was a severe blow, both to the Esperanto vision of a united mankind, and to the practical reality of transnational connections within and from Europe. However, whilst the Japanese movement was reduced in terms of the size and scale of its activity, it nevertheless continued to develop new ideas and new practices. Indeed, in the absence of European influence, in some respects it was freer to develop independently. Many of the leading figures from 1906 continued to play significant roles, whilst a second generation of Japanese Esperantists began to emerge, laying the ground for what was to be a great resurgence in Esperanto, in Japan as it was overseas, when the First World War came to an end.

The Esperanto scene in Japan which developed during the mid-late 1910s was but one part of a growing set of transnational connections with Tokyo at their heart. With the 
European war as an inhibiting factor, many of these developments touched other parts of Asia, rather than looking further west. However, one central symbol of this growing Tokyobased transnationalism was European: the Ukrainian, Vasily Eroshenko.

Eroshenko was an unusual European visitor to Japan in several respects. Most immediately and obviously, he was blind, the result of a childhood illness. But perhaps more significantly, in contrast to the waves of European traders, missionaries, educators, scientists and engineers, who brought with them European technology or knowledge or ways of doing business, Eroshenko came to Japan not to teach, but instead to learn. Prior to coming to Tokyo in 1914, Eroshenko had studied in blind schools in Moscow and London; he was drawn to Japan, reportedly in order to study massage, one of the traditional occupations of the Japanese blind.

Eroshenko was by nature inquisitive and gregarious, and his open personality appealed to many, so the Japanese Esperanto movement was only one of a number of different groups within which he made friends. Between 1914 and 1921, when he left Japan for the last time, Eroshenko was involved with young blind activists, student groups, political radicals, artists and writers, and more besides, weaving a rich web of connections, transnational and otherwise.

One example of the impact that Eroshenko had on his Japanese friends was his relationship with Akita Ujaku. Akita, a playwright and writer based in Tokyo, met Eroshenko in late 1914, at a time when, although he was beginning to make a name for himself, he was struggling to support his wife and children. Things had reached such an extreme that, looking back years later, he speculated that he might even have committed suicide. ${ }^{17}$ The impact that meeting Eroshenko had on him was transformative. The blind Russian's positive outlook on 17 Akita Ujaku, Ujaku Jiden (Shin Hyōronsha, Tokyo) p.50. 
life and its possibilities helped Akita to take on a new perspective himself, and Esperanto was one key element of this. The day after meeting Eroshenko, Akita began to study the language, attending meetings and experimenting with it in his diary. ${ }^{18}$ From there, he joined Eroshenko in exploring the networks of transnational possibility opening up in Tokyo.

Both Eroshenko and Akita became involved with the Bahá'í mission to Japan. Bahá'í, a Persian religion, established a presence in Tokyo in 1914, at the same time as Eroshenko arrived, through the person of Agnes Alexander, an American daughter of two missionaries to Hawaii. ${ }^{19}$ Bahá'í's teachings included the establishment of Esperanto as a medium for world communication, so Agnes Alexander became a regular presence within the Japanese Esperanto scene in the early Taishō years, and Japanese Esperantists often visited her Bahá'í meetings in return. Although neither Akita nor Eroshenko became followers of the faith, both were close with Alexander and sympathetic to her cause, helping her with translations and by writing about Bahá'í in mainstream press. ${ }^{20}$

Another group in which Akita and Eroshenko both participated was the literary salon run by Sōma Kokkō and her husband Aizō. The couple were the proprietors of a bakery, the Nakamuraya, in Shinjuku. ${ }^{21}$ Behind the bakery was a western style studio, which was home at various times to several artists and writers, Eroshenko included. ${ }^{22}$ The salon met there, and in the rooms above the bakery. Eroshenko became close to both Sōma Kokkō and Sōma Aizō, playing Russian music on the balalaika and violin, participating in discussions of Russian literature (a particular interest to Kokkō, who studied the language for a time with a view to

18 Akita Ujaku, Akita Ujaku Nikki Vol.1 (Tokyo, Mirai-sha) p.11.

19 D Troxel. '70 Years of Service' (Osaka, Bahai Publishing Trust) Chapter 2.

20 Agnes Alexander and Barbara Sims, History of the Bahai Faith in Japan (Osaka, Bahai Publishing Trust) p.15, p. 21 .

21 Aizō Sōma, Ichi-Shōnin to Shite, reproduced in Kokkō Chōsaku Shū (Nagano, Kyōdo Shuppan-sha).

22 Akita, Akita Ujaku Nikki Vol.1, p.46 
travelling to Moscow), and sitting as a subject for some of the artists who also participated in the salon. ${ }^{23}$

Both the Nakamuraya and the Bahá'í were, in turn, closely associated with the visit to Japan of the poet, Rabindranath Tagore. Tagore had been awarded the Nobel Prize for literature in 1913 - the first Asian recipient. He came to Japan in 1916, on a lecture tour sponsored by the Asahi Shinbun, before continuing on to America. The Asahi promoted his visit relentlessly, such that his talks and public appearances were met by vast crowds. ${ }^{24}$ Although he doesn't appear to have had a direct interest in Esperanto himself, many of the Japanese Esperantists were fascinated by Tagore's visit. For example, Akita Ujaku followed the news of Tagore's progress across the Indian Ocean, reading both Tagore's own work and also Indian philosophy. Together with Eroshenko and the members of a literary society Akita had founded called the 'Red Hat Society', Akita joined a crowd estimated at 25,000-30,000 to see Tagore arrive at Tokyo station. Akita and his society shouted an Esperanto greeting to Tagore across the crowds. ${ }^{25}$ Akita, Eroshenko and Agnes Alexander attended Tagore's highest profile talk, at the Imperial University, whilst Tagore made visits to both the Nakamuraya and the Bahá'ís. ${ }^{26}$ Tagore had a message of caution for Japan, warning that shallow modernisation threatened Japan's unique connection with the natural world. ${ }^{27}$ This was met with a mixed response by the Japanese audience; for their parts, Akita Ujaku reacted positively the Indian

23 Two portraits resulted: the more famous of the two, Eroshenko no Zō by Nakamura Tsune, came to be celebrated as a highlight of Japanese western-style art, even as, Eroshenko himself was expelled from the country.

24 Stephen N Hay, Asian Ideas of East and West; Tagore and His Critics in Japan, China, and India (Massachusetts, Harvard University Press) p.62.

25 Akita, Akita Ujaku Nikki Vol.1, p.59. The Red Hat Society seems to have been named in connection to the red fezzes worn by followers of Bahá'ísm.

26 Asahi Shinbun, 12 June 1916; the Nakamuraya website (www.nakamuraya.co.jp/photo/index.html, accessed August 2014) has a photo of Tagore with Sōma Kokkō, together with her son in law, the Indian nationalist, Rash Behari Bose, whilst there is one of him with the Bahá'ís in Barbara Sims, Traces That Remain: A Pictorial History of the Early Days of the Bahá'í Faith among the Japanese (Tokyo, Bahá'í Publishing Trust of Japan) p.35.

27 See, for example, Rabindranath Tagore, The Spirit of Japan (Tokyo, Indo-Japanese Association). 
philosophy he read but was more ambivalent regarding Tagore's own message, whilst Eroshenko was reportedly hostile to Tagore's ideas of an east/west divide along spiritual/material lines. ${ }^{28}$

As it happened, in the midst of Tagore's tour of Japan, Eroshenko left Japan on his own tour of a series of Asian countries. He made use of the networks and contacts he had made in Tokyo to find support, visiting Siam, Burma, and finally India. He was in Burma in 1917/18 when the news of the Russian Revolution began to reach Asia, so he endeavoured to return home. However, he was unsuccessful: in late 1918 he was put under house arrest in Calcutta and ultimately deported back to Japan. ${ }^{29}$

Back in Tokyo, Eroshenko picked up where he had left off. By this time, the post1918 resurgence Esperanto was in full swing. Socialism in Japan, too, was waking from its 'winter period', and several of Eroshenko's circles, such as the student group, the Shinjin-kai (which also experimented with Esperanto as a means for involving Chinese and Korean students) were engaged with the left. This proved Eroshenko's undoing. The documents relating to his expulsion from India had marked him as a proponent of 'extremist thought' and in 1921 he was twice arrested at socialist events: the May Day march of the first of May, and the AGM of the Nihon Shakaishugi Dōmei (the Japan Socialist League) on the ninth. ${ }^{30}$ The press displayed shock at these arrests and then later, at the news that he was to be deported. ${ }^{31}$

28 Hay, Asian Ideas of East and West, p.83; Akita, Akita Ujaku Nikki Vol.1. p.66; Takasugi Ichirō, Yoake Mae No Uta (Tokyo, Iwanami Shoten) p.142. Yoake Mae No Uta is a popular account of Eroshenko's life, rather than a scholarly one, and I have been unable to find a more authoritative reference for the claim that Eroshenko disagreed with Tagore, although it is made elsewhere too. Given that Tagore visited the Nakamuraya and the Bahá'ís, it is entirely plausible that they met face-to-face.

29 Takasugi, Yoake Mae No Uta, Chapters 19-22.

30 'Tokubetsu Yōshisatsujin Jōsei Ippan \#6 \& \#9', in GSS, Zoku Gendaishi Shiryō, Volume 1-2: Shakai Shugi Enkaku, (Tokyo, Misuzu Shobō) p.487, p.699; 'Mēdē wo Uta Takarakani Rōdōsha Kozotte', Osaka Mainichi Shinbun, 2 May 1921.

31 For example, 'Kare ha Naita', Asahi Shinbun, 29 May 1921, featuring a photograph of Eroshenko receiving the deportation order. 
Eroshenko was arrested in the Nakamuraya; this sparked a campaign for his release from a range of figures - those on the left such as Akita Ujaku and the famous liberal journalist Hasegawa Nyozekan, but also less radical figures from within the Esperanto scene including Kuroita Katsumi. ${ }^{32}$ Their appeals were to no avail, however, and Eroshenko was taken by train out of Tokyo, to be shipped out of Japan through Kobe. Ironically, expelled from India and Japan on the grounds of his radicalism, he was unable to prove his revolutionary credentials, and was denied entry to the Soviet Union. Adrift, he made use once again of the burgeoning transnational networks across Asia, finding a new home teaching Esperanto in China, first in Shanghai and later in Beijing. ${ }^{33}$

Not all who took part in the circles of transnational activity through which Vasily Eroshenko passed were Esperantists. However, many were, and the language surged in popularity from 1918 into the early 1920s. ${ }^{34}$ Kuroita Katsumi stepped back from an active role in the leadership of Japanese Esperanto, replaced by members of the younger generation, and there was a move from pragmatism towards idealism in the motivating philosophy for the language: a debate within the movement was won by the advocates of a progressive vision of Esperanto over those who argued for a position of explicit political neutrality. Although he left Japan as these changes were taking place, Eroshenko was a human representation of some of the new ideas: optimistic, idealistic, and willing to place his fate in the support of others, whether he was in Tokyo, Japan, or across Asian and beyond.

32 'Taikyo Mae no E-shi no Kokubetsu wo Yūjintachi ga Naishō ni Mōshideru', Yomiuri Shinbun, 3 June 1921. 33 Müller-Saini \& Benton, 'Esperanto and Chinese Anarchism in the 1920s and 1930s', p.176.

34 It is tempting to characterise this broad network as a form of cultural internationalism, indeed it is certainly one key interpretation. However, there were also links to other groups which argue that the full comprehension of this Taisho era transnationalism demands a more nuanced understanding. For example, see the Nakamura-ya's connections to the far right through the likes of Toyama Mitsuru (see Eri Hotta, 'Rash Behari Bose and His Japanese Supporters: An Insight into Anti-Colonial Nationalism and Pan-Asianism', Interventions 8:1 (2006)). 


\section{Encounters through Language - Japanese Esperantists abroad}

The second wave of Japanese Esperanto was larger, longer lasting, and more sophisticated than the first. ${ }^{35}$ Buoyed initially by the global 'Wilsonian moment' and associated forms of cultural internationalism, the membership of the Japanese Esperanto associations and clubs grew throughout the 1920s. ${ }^{36}$ Increasingly, in addition to developing their domestic movement, Japanese Esperantists were active overseas, representing Japanese perspectives in a growing range of European debates as well as carrying the movement onto continental Asia. The socialist connections to Chinese Esperanto continued, even after the death of Ōsugi Sakae in 1923, whilst there were also mainstream Esperanto groups in Korea, Taiwan, and in the Japanese settlements in Manchuria. ${ }^{37}$

Within a colonial setting, however, Esperanto took on a different range of potential meanings. The Japanese authorities took a dim view of the first clubs in Taiwan until a leading Japanese Esperantist, Nakamura Kiyō, head of the Japanese meteorological office, intervened on their behalf whilst visiting in $1915 .{ }^{38}$ For the native Taiwanese, trapped between Japanese colonial policy on one side, and mainland Chinese culture on the other, the question of vernacular language and script was a pivotal one to local identity, one that was debated throughout the early twentieth century, with Esperanto featuring in the debate, linked

35 With the emergence of this second wave the Japana Esperantista-Associa, the JEA, was eventually replaced by the creation of a new body, better organised and reflecting some of the more open principles of the new era. The new organisation was known as the Japana Esperanto Instituto, the JEI, and remains today the central association for Japanese Esperantists.

36 Erez Manela, The Wilsonian Moment: Self-Determination and the International Origins of Anticolonial Nationalism (Oxford, Oxford University Press); Akira Iriye, Cultural Internationalism and World Order (Baltimore, Johns Hopkins University Press).

37 The key figure in ongoing anarchist connections to Chinese Esperanto was Ōsugi's disciple, Yamaga Taiji, whilst a separate network of communist/Marxist influence developed during the 1920s.

38 Nakamura's status as a leading scientist and member of the Japanese establishment was sufficient to sway official opinion. Fukuda Masao, Katō Kōichi \& Sakai Matsutarō, Esuperanto Binran (Tokyo, Yōbunsha) p.72. 
to other ideas, such as romanisation. ${ }^{39}$ Perhaps because of this, Esperanto remained a contentious issue. In 1922, with the worldwide spread of Esperanto continuing at its fastest pace, La Verda Ombro ('Green Shadow'), the Taiwanese Esperanto Association's magazine, reported a conversation with a Japanese official revealing lingering suspicions regarding the use of Esperanto by the local population:

Despite studying the same Esperanto, whereas for the Japanese the choice is undoubtedly simply as an international language of world exchange, a symbolic language of the inevitable rise of racial harmony, or perhaps a result of the love of the Japanese language; in the case of a Taiwanese the conditions are different. For them it is not the case of practising a world language as one of the peoples of the world; quite the opposite, it is fully imbued with the meaning of opposition to the Japanese language. Since language and thought have a relationship of connection, rejecting the Japanese language must be seen as rejecting Japan itself. The Japanese colonial policy must not tacitly allow such rebellion. ${ }^{40}$

This interview took place the year after Vasily Eroshenko was expelled from Japan, an event which led to reports that the Home Ministry was investigating the possibility that the Esperanto movement was little more than a cover for the radical left. ${ }^{41}$ However, the size and complexity of the state was such that its response to Esperanto was neither uniform nor consistent. Whilst some parts of the Japanese state was looking at Esperanto with hostility, other parts were exploring it from a more positive perspective. The period of the second wave of Japanese Esperanto growth was one in which the Japanese state was committing in earnest to diplomatic ideas of internationalism emerging from the post-First World War settlement,

39 Jing Tsu, Sound and Script in Chinese Diaspora, (Massachusetts, Harvard University Press), Chapter 6: The Missing Script of Taiwan.

40 La Verda Ombro, April 1922, quoted in Masao and Yoshio, Hantaisei Esuperanto Undo-Shi, p.94.

41 'Shakai shugi wo Niramu’, Yomiuri Shinbun, 30 May 1921. 
and in that setting Esperanto was seen quite differently to the Taiwanese official's suspicion or the concern of the domestic Japanese authorities about ties to communism. During the early 1920s, Japan was a diligent member of the international community, centred upon its permanent membership of the League of Nations' Council. When questions of international language arose at the League, the Japanese delegation took them seriously.

The first mentions of Esperanto at the League came in the very first plenary sessions of the first year of operation. From there, Esperanto featured in a number of settings, from the main debating chamber, to a report filed by Nitobe Inazō, to specialist sub-committees and the general informal activities surrounding the League. Although the ultimate result of these considerations was rejection - the recommendation that an artificial language was not the answer to problems of international language, nevertheless this serious consideration by some of the members of the League marked a high-point in Esperanto's international history and a recognition of its increasing worldwide profile. $^{42}$

Japan occupied an unusual position at the League of Nations - at once both a member of the inner circle (a permanent member of the Council, and supplying vital positions such as that of Nitobe, Under-Secretary General, the second highest ranking member of the League's civil service) and yet also a relative newcomer and outsider - a rare independent Asian participant, and one with a limited history of diplomatic contact. Thus, when questions of language in diplomacy arose, Japan's position, too, was a complex one.

When Esperanto was first introduced to the League, Japan was reported as siding with a French attempt to forestall consideration, but in subsequent years the official Japanese

42 The rejection of Esperanto is widely considered to have been the work of the French at the League, keen to protect their own language's traditional role in the centre of diplomacy. For a full account of the passage of Esperanto through the League, see PG Forster, The Esperanto Movement, Chapter 6. 
position changed to one supporting its consideration at the League. ${ }^{43}$ In addition to this official position, there were a number of Japanese participants at the League who had personal or individual views on the debates.

Nitobe Inazō is widely recognised as one of the most famous supporters of Esperanto in its twentieth century history. He attended the annual Esperanto congress in Prague in 1921 at the invitation of the Universal Esperanto Association; on his return he wrote a report of the congress and wider considerations of language at the League. Despite a thorough-going attempt to avoid taking a position on the question, this report was considered to be a major act of support for the language, given its recognition of the existence of an international language problem', and the stress on the importance of equality and neutrality in its solution. $^{44}$

In writing the report, Nitobe was acting, not as a representative of the Japanese government, but rather as an agent of the League itself. Whilst he seems to have made little or no actual effort to learn Esperanto, he lectured on the language back in Japan and was described by friends as being a supporter. ${ }^{45}$ There were others amongst the Japanese participants in League affairs, however, who were more deeply involved with learning and using Esperanto. Firstly, Fujisawa Chikao, another Japanese employee of the League's administrative staff, the Secretariat, had been a major voice in the Tokyo Esperanto scene in the late 1910s. A talented linguist like Nitobe, Fujisawa's view of Esperanto was coloured by

43 Advocates of Esperanto never went so far as seeking to have the League adopt Esperanto itself, but merely sought to have an official League statement endorsing its further development and spread. Nevertheless this relatively modest proposal appears to have been seen by many as a stalking horse for the idea of ultimately introducing Esperanto more widely into diplomatic affairs. There is also a question of personality involved in the Japanese change in stance: Ishii Kikujirō, the main Japanese representative to the League, was reportedly hostile to Esperanto, at least at first, whilst it was another senior diplomat, Adachi Mineichirō, who was the signatory when Japan joined the list of nations supporting the Esperanto motion.

44 Nitobe Inazō, Esperanto and the Language Question at the League of Nations (Geneva, League of Nations).

45 Fujisawa Chikao, La Revuo Orienta, January 1921, p.2; Nagata Hidejirō, 'Nihon Kokumin to Esuperanto', La Revuo Orienta, December 1933, p.342; Junebe no Omoide, Kunio Yanagita, in Teihon Yanagita Kunio Shù (Tokyo, Chikuma Shobō) Additional Vol.3, p.311. 
his experience of the difficulties many of his countrymen found in learning and using foreign languages ${ }^{46} \mathrm{He}$ had been involved a range of official Japanese international activities; at each point he saw Japanese linguistic limitations hampering national objectives. The League was no exception; as he wrote:

I fear that the delegation recently sent from Japan [to the League] will repeat the same failure [as prior Japanese missions] due to inability at French and English. Thus the adoption of Esperanto as the sole language of international communication would be a very opportune proposal for the interests of Japan. ${ }^{47}$

Yanagita Kunio, the last major Japanese actor in the Esperanto activities surrounding the League, served as an immediate proof of Fujisawa's views. Yanagita, like Nitobe and Fujisawa, was not strictly a member of the Japanese delegation to the League - he was in Geneva to serve on the Permanent Mandates Commission, a body set up to oversee the management of the League's Mandates - ex-colonies of the defeated First World War powers that were administrated for the League by its leading members, Japan included. Despite an elite education and being well read in European scholarship, Yanagita rapidly found that speaking and listening in foreign languages was much harder than reading and writing, and he struggled to participate fully on the commission. Ultimately, this frustration led Yanagita to quit the League and to return to Japan, but before he did so, he turned to Esperanto as a possible solution to his, and others', problems. As he recalled:

At just that time, there was a movement underway for the recognition of Esperanto at the League, and the reason for the greater than usual interest that I had in it was straightforward: if adopted, I too could express what I thought. Further, it valued the smaller nations: because

46 Usui, 'Kokusaiha Kara Okkuruto Nashonarisuto He'.

47 Fujisawa Chikao, La Revuo Orienta, January 1921, p.2. Fujisawa was also dismissive of the linguistic abilities of the major Japanese representatives at the League, in particular Ishii Kikujirō and Hayashi Gonsuke, ambassadors to France and the UK respectively. 
those [League] representatives who were not diplomats were all suffering; even if it were not to reach the level of [usage of] English or French, I thought that it might be more freely used. $^{48}$

Yanagita recommended Esperanto to his friends, met with Esperantists whilst back in Japan, and attended a range of meetings in Geneva, which he described in his letters, mentioning the diverse contacts that he made, and speeches he listened to. Whilst it has been suggested that Yanagita's time at the League was one of isolation, in which he would note in his diary, 'I did not see a single Japanese face the whole day', ${ }^{49}$ it was nevertheless one in which he also wrote letters back to Japan telling of his Russian Esperanto teacher, his trip to a club in Venice, and the international gathering that came together to celebrate Zamenhof's birthday. ${ }^{50}$ Yanagita continued to advocate Esperanto throughout the 1920s, assisting with the official incorporation of the JEI, and arguing that through Esperanto, Japanese scholars might get a wider audience for their work..$^{51}$

Yanagita's language problems at the start of the 1920s were matched by another example of Japanese transnational activity towards the end of the decade: that of Akita Ujaku. ${ }^{52}$ Akita had continued to practice Esperanto after his friend Eroshenko had been deported, remaining a leading figure on the left of the movement. In 1927 he, like Yanagita before him, had the chance to make use of the language overseas for the first time, albeit in a very different setting, when he travelled to the Moscow to take part in the celebrations of the tenth anniversary of the October Revolution.

48 Yanagita, Teihon Yanagita Kunio Shü. Ad. Vol.3, p.311

49 Oguma Eiji, A Genealogy of 'Japanese' Self-Images, (Melbourne, Trans Pacific Press) p.183

50 Yanagita, Teihon Yanagita Kunio Shū. Ad. Vol. 4, p.475, p.480

51 Yanagita Kunio, 'Nihon ga Buntan subeki Ninmu', La Revuo Orienta, Janaury 1927, p.1.

52 Indeed, Yanagita and Akita were linked directly: when Yanagita recommended Esperanto to his colleagues and friends back in Japan, such as long-time collaborator Sasaki Kizen, he suggested that they get in touch with Akita Ujaku, Sasaki Kizen, Sasaki Kizen Zenshu, Vol.4, (Tono, Tono City Museum) p.227. 
The trip was well organised: Akita spent much of 1927 studying Russian, securing support from magazines and newspapers who published his reports of the celebrations, and dealing with his passport and visas. ${ }^{53}$ When he finally set off, together with a friend from his hometown, Narumi Kanzō, a specialist in Russian literature, it was a with a sense of euphoria, singing the unofficial anthem of the Esperanto movement, La Espero, as they crossed into the Soviet Union, together with some Russians they had met on the train. ${ }^{54}$ The trip was to prove a first-hand realisation of Akita's belief in both the new Soviet system and the importance and value of Esperanto as a means of international communication.

Akita and Narumi arrived in Moscow on the $13^{\text {th }}$ of October; ultimately Akita extended his initial visa and ended up staying until the Moscow May Day celebrations of 1928, finally returning to Tokyo on the $18^{\text {th }}$ May that year (for his part, Narumi remained behind in Moscow for a further 9 years). In many respects the visit was typical of a 'fellow traveller's' experience in the new Soviet Union: hosted by the 'All Union Society For Cultural Relations With Foreign Countries' (VOKS) and taking in visits to theatres \& factories, meetings \& official celebrations, and featuring a wide range of other people Russians, fellow Japanese and other nationalities. ${ }^{55}$

However, language proved a problem for Akita in Moscow, just as it had for Yanagita in Geneva. VOKS provided Akita with a translator for much of his time, and he also met up again with his old friend Vasily Eroshenko, who helped him to study Russian, ${ }^{56}$ but despite these and the presence of Narumi Kanzō, he noted immediate problems. After the first day of the centrepiece of the celebrations for international delegates, a Congress of Friends of the

53 Akita Ujaku, Akita Ujaku Nikki, vol. 2.

54 Ibid. p.35

55 Ludmila Stern, Western Intellectuals and the Soviet Union, 1920-40: From Red Square to the Left Bank (London, Routledge) outlines the experiences of Western intellectual visitors to the Soviet Union in the same period.

56 Akita, Akita Ujaku Nikki Vol.2. p.38. 
Soviet Union, Akita wrote in his diary simply 'Congress of the Friends of the Soviet Union' opened... language problems; Ruikov's speech: the translation was very difficult.'. ${ }^{57}$ However, whilst at the congress, Akita met two leading Esperanto supporters from Europe: Henri Barbusse from France, and Earnest Drezen from the Soviet Union. Encouraged by them, he went on to propose a motion supporting Esperanto for consideration by the congress. ${ }^{58}$

Whilst the motion was not passed, Akita went on to make widespread personal use of Esperanto. For the most part, he made less of the formal elements of his visit than the informal ones - he regarded the central parade of the de-centennial celebrations as disappointingly militaristic, but he increasingly met with more and more varied people outside of the official events. In this regard, Esperanto was not only a means for talking to Russians and the 30-odd foreign Esperantists he met amongst the foreign delegates in Moscow, it opened a door to a wider set of experiences of Soviet life. Akita made a set of broadcasts on Soviet radio in and about Esperanto, and he attended meetings of a club in the PTTR (Post Telegraph Telegram and Radio) department; from these starting points, his Russian Esperanto contacts snowballed. The radio broadcast led to an invitation to Minsk, and the PTTR meetings led to a series of more informal meetings with Russian Esperantists and thus a deeper experience of Soviet society: 'Once I made some Esperanto friends, I was able to use their linguistic aid to enter the real life of Moscow - through an Esperanto teacher called Zavoronokov, I was able to make contact with workers' daily lives, home, factory, and club lives' ${ }^{59}$

57 Ibid. p.44.

58 Ibid. p. 45 .

59 Akita, Ujaku Jiden. p.147; see also Esuperanto, August 1928, p.138. 
Esperanto, then, was at the heart of Akita's most positive experiences in Moscow, and in turn the trip was immense personal importance to him. Back in Tokyo, he published the collection of his reports from Moscow as a book, Wakaki Sobeito Roshia, he lectured on his experiences, and he formed a research association, the Puroretaria Kagaku Kenkyūkai (the Proletarian Science Research Association), seeking to spread and develop the knowledge that he had gained. But before he made it back to Japan, riding the train back across Siberia, he had one final chance to reflect on the need for an international language. Sharing the carriage with some fellow reform-minded Chinese students, also on the journey home from Europe, he marked the futility that 'whilst we were the same mankind, humans with the closest relationship of interests, because of the constraints of language we could not exchange these intents'. ${ }^{60}$

\section{Conclusion}

Akita's return to Tokyo coincided with the emergence of a distinct proletarian Esperanto movement, with its own organisations, textbooks, and meetings separate from the mainstream institutions which had existed to date. What had been a diverse, but integrated movement, bringing together groups with different motivations and intellectual perspectives with a good degree of harmony, increasingly split into two. The wedge between the two Esperanto groups was driven by a mix of internal and external stresses - the hostile stance of the broader proletarian movement regarding 'bourgeois internationalist' groups from within and the aggressive government suppression of communist-linked groups from without. Old Esperanto hands who embraced the proletarian ideology, such as Akita Ujaku, faced a difficult decision in cutting ties with old friends, whilst those within the mainstream movement were

60 Ibid. p. 151 
understandably keen to avoid their activities being perceived as linked to the increasingly persecuted proletarian movement.

Thus whilst Esperanto activity, and transnational encounters, continued to take place into the 1930s on both sides of the bourgeois/proletarian divide, the period from 1928 to about 1932 saw a real change in the nature of the Japanese Esperanto network.

Each phase, from the immediate wake of the Russo-Japanese War, to the Taishō period and 1920s, and then further developments during the 1930s (and indeed again in the post-war period) saw the type and nature of the transnational encounters through Esperanto changing in response to political, social, and technological context. However, whilst each generation revealed a different set of activities and ideas, running through them all was the common desire to make a concrete connection with the wider world, and the recognition of the vital role that language played in the act of engagement. 


\section{Bibliography}

Akita, U., Akita Ujaku Nikki, 3 vols., Tokyo: Mirai-sha, 1965.

—. Ujaku Jiden, Tokyo: Shin Hyōronsha, 1953 (reprinted, 1987).

Alexander, A., and Sims, B., History of the Bahai Faith in Japan, Osaka: Bahai Publishing Trust, 1977.

Cheah, P., and Robbins, B., Cosmopolitics: Thinking and Feeling Beyond the Nation, Minnesota: University of Minnesota Press, 1998.

EPA, Kvindek Jaroj De Esperanto En Oomoto, Kameoka: Esperanto-Propoganda Asocio, 1973.

Forster, P. G., The Esperanto Movement, The Hague: Moulton, 1982.

Fujima, T., Kindai Nihon Ni Okeru Kokusaigo Shisō No Tenkai, Osaka: Japana Esperanto Librokooperativo, 1978.

Fukuda, M., Katō, K. \& Sakai, M., Esuperanto Binran, Tokyo: Yōbunsha, 1967.

GSS, Zoku Gendaishi Shiryō, Volume 1-2: Shakai Shugi Enkaku, Tokyo: Misuzu Shobō, 1982.

Hatsushiba, T., Nihon Esuperanto Undō-Shi, Tokyo: Japana Esperanto-Instituto, 1998.

Hay, S. N., Asian Ideas of East and West; Tagore and His Critics in Japan, China, and India, Massachusetts: Harvard University Press, 1970.

Hotta, E., 'Rash Behari Bose and His Japanese Supporters: An Insight into Anti-Colonial Nationalism and Pan-Asianism', Interventions 8:1 (2006), pp.116-32.

Howland, D., Translating the West: Language and Political Reason in Nineteenth-Century Japan, Hawaii, University of Hawaii Press, 2002.

Inazō, N., Esperanto and the Language Question at the League of Nations, Geneva: League of Nations, 1921.

Iriye, A., Cultural Internationalism and World Order, Baltimore: Johns Hopkins University Press, 1997.

Itō S., Takaku Takaku, Tōku No Hō E, Tokyo: Tettō Shoin, 1974.

JEI, Wakayama to Esuperanto, Tokyo: Japana Esperanto-Instituto, 2008.

Konishi, S., 'Translingual World Order: Language without Culture in Post-Russo-Japanese War Japan', The Journal of Asian Studies 72:1 (2013), pp.91-114.

Lins, U., 'Esperanto as Language and Idea in China and Japan', Language Problems \& Language Planning 32:1 (2008), pp.47-60.

Manela, E., The Wilsonian Moment: Self-Determination and the International Origins of Anticolonial Nationalism, Oxford: Oxford University Press, 2007.

Masao, M., and Oshima Y., Hantaisei Esuperanto Undo-Shi, Tokyo: Sanshodo, 1973.

Mukai, K., Anakisuto to Esuperanto: Yamaga Taiji Hito to Sono Shogai, Himeji: Seigabō, 1974. 
Müller-Saini, G., and Benton, G., 'Esperanto and Chinese Anarchism 1907-1920: The Translation from Diaspora to Homeland', Language Problems \& Language Planning 30:1 (2006), pp.45-73.

— Language Planning 30:2 (2006), pp.173-192.

Nihon-Esuperanto-Gakkai, Nihon Esuperanto Undō-Shiryō: Vol 1 1906-1929, JEI ed., Tokyo: 1956.

Oguma, E., (translated by Askew D.), A Genealogy of 'Japanese' Self-Images, Melbourne: Trans Pacific Press, 2002.

Oka K., Okayama no Esuperanto, Okayama:Okayama Bunko \#108, 1988.

Sasaki, K., Sasaki Kizen Zenshu, Vol. 4. Tono: Tono City Museum, 1986.

Sims, B., Traces That Remain: A Pictorial History of the Early Days of the Bahá'i Faith among the Japanese, Tokyo: Bahá'í Publishing Trust of Japan, 1989.

Sōma, A., 'Ichi-Shōnin to Shite', in Kokkō Chōsaku Shū, Nagano: Kyōdo Shuppan-sha, 1996.

Stern, L., Western Intellectuals and the Soviet Union, 1920-40: From Red Square to the Left Bank, London: Routledge, 2007.

Tagore, R., The Spirit of Japan, Tokyo: Indo-Japanese Association, 1916.

Takasugi, I., Yoake Mae No Uta, Tokyo: Iwanami Shoten, 1982.

Troxel, D., 70 Years of Service, Osaka: Bahá'i Publishing Trust, 1983, http://bahailibrary.com/troxel alexander_70-years_service [Accessed July 2014].

Tsu, J., Sound and Script in Chinese Diaspora, Masachussetts, Harvard University Press, 2010.

Usui, H., 'Kokusaiha Kara Okkuruto Nashonarisuto He', Japana Esperantologio 4 (2010), pp.3-20.

Yanagita, K., Teihon Yanagita Kunio Shū, Tokyo: Chikuma Shobō, 1966-7.

Yoshikawa, S., Naka San'nin Okareta Hito, Osaka: Riveroij Sosho, 1996. 